\title{
The Impasse of Ancient Tragical Weltanschauung and Two Positive Ways out*
}

\author{
Andrei Paribok \\ Department of Cultural Studies and Philosophy of the East \\ St. Petersburg State University \\ Institute of Philosophy \\ St. Petersburg, Russia \\ E-mail: paribok6@gmail.com
}

\begin{abstract}
The paper deals with the reconstructed logic of the historical conceptual change of ideal worldview types in the early history of Indian and Western civilizations. The primordial naturalistic outlook characterized by prereflexivity and a total neglect of human subjectivity was first superseded by elitist tragic or heroic Weltanschauung, within which emerged the first version of human personality as distinguished and separated from the outer world. The tragic vision of life, however, proved to be unfit to become universally accepted because of its unbearable burden of impersonal fate. We call this situation a tragic impasse. The further development of ideas demonstrates two positive attempts to solve this existential problem. These widely accepted alternatives are a monotheism with personal supranaturalistic God and a karmic worldview. Both suffice.
\end{abstract}

Keywords—worldview; typology; monotheism; tragic; karma; values; hero; faith; subjectivity; historical psychology; philosophy

\section{INTRODUCTION}

Whatever a possible worldview may be, any need in it seems to be sensible only in a case of individual whose mind is necessarily not omniscient. The omniscience itself can be conceived of as being either static or dynamic. The first one deserves the name of an actual epistemic infinity and was sometimes ascribed to the Lord as one of His essential attributes by theologians of monotheistic religions. The divine reason is thought of as having constant, or even eternal, knowledge of anything and everything. The second dynamic alternative corresponds to a potential epistemic infinity. This notion is appropriate to explain tendencies of Buddhist or Jainist speculations. A Buddha or a Tirthankara does not contain in his mind knowledge of every possible object but has the ability to acquire it immediately and without any difficulty whenever needed. In both cases an infinite mind does not require a general worldview as a prerequisite, heuristic component \&c for understanding a situation, solving any problem or decision-making because every possible problem is being grasped and solved perfectly with ultimate individual precision. An odd theoretical assumption a playful infinite mind, which finds predilection

*The paper is supported by the grant of the Russian Science Foundation (RSF) No. 16-18-10427. in amusing himself with abstract general concepts, nit for the sake of cognition or action, let be disregarded as irrelevant. To conclude, a general worldview, an essentially not precise overview of everything, is inevitably necessary for finite minds and finite sentient beings only, including humans. As a characteristic of a finite mind, it is finite itself, moreover, it does not encompass all cognitive abilities and horizon of a finite mind because the latter is in some crucial cases capable to improve its worldview. Positively, any worldview contains a most general frame of understanding and evaluation of phenomena, entities, situations \&c, but is also characterized negatively by some blind spots viz. neglected problems an (or) objects which may be clearly visible and evaluated as important in a perspective of another worldview.

\section{The Tragic IMPASSE AND Two Alternative RESCUES}

According to modern common sense, it seems almost obvious that in any worldview are to be accounted for some essential characteristics of (a) of the objects within the world, (b) the world as a whole and finally (c) its proponent, viz. the very individual whose worldview it is (compare Heideggers's description of Dasein as In-der-Welt-Sein), his possible place in the universe and his values. But this third subjective or reflective facet, which treats the existential position of a worldview's upholder, has been a result of a historically complicated conceptual elaboration and was lacking in early Antiquity virtually altogether. The ancient man (and the ancient woman even more so) was not yet puzzled by painful questions about the determinants of his or her unique individual life's crucial events. For him or her, everything in somebody's life including his own one occurred uniformly and in an impersonal manner. This type of the worldview, which doesn't afford any place and attention to the subjectivity of its subject, we shall call, a bit metaphorically, naturalistic. Its main value was invariably maintenance of the existing world. Strictly speaking it was a pre-personal, totally submerged in the objects, pre-subjective, essentially static outlook. Its possible and known varieties are numerous and rather diverse, e.g. the Chinese traditional philosophy of Yin, Yang and five elements as basic principles, all early forms of religion, any polytheism. But, astonishing enough, to this type of the world outlook belong 
also such contemporary varieties as the modern scientism, positivist philosophy and the behaviorism in psychology. The concretization and scope of the notion of "natural" in these heterogeneous examples is scarcely comparable but this notion invariably remains all-encompassing due to naive or methodical (in the case of behaviorism) exclusion of the subject, of me as me. Its semiconscious conviction can be expressed by a motto "In my thinking, I do not take my existence seriously and as indispensable for my worldview".

The first historically significant and imperishable attempt to transcend the naturalistic perspective and thereby to introduce a genuine subject as an autonomous actor who doesn't necessarily conform to his factual position in the world is the heroic or tragic vision. Both Greek epithets are equally pertinent. It is also the first successful endeavor in this field, which did not fall into oblivion (this had been the case of a significantly earlier unprecedented Gilgamesh epics). Moreover, it produced further conceptual development. It is well documented both in Ancient Indian and Ancient Greek literatures. In India, the greatest literary work that conveys this worldview is Mahābhārata and the most tragical hero is Karna [1], whereas in Greece this vision is expressed e.g. in such masterpieces of Athenian tragiographer Sophocles as Oedipus Rex or Philoctetes. Within it, there emerges an unprecedented figure of a tragic hero in the strict sense of the word. The following features characterize him. 1. As to his position in the "natural" order of things in the world, he is an eminent individual (in Mahābhārata he is called mahābhāga "one to whom a great portion or lot has fallen"), e.g. a ruler of a noble origin, and has the ability to perform great deeds. But this feature is by no way sufficient to make him a tragic hero: the naturalistic worldview is also very well aware of the notion of a worldly grandeur but in its factual positivistic trend it will represent a great individual as regularly successful in his endeavor. So, the factual position within the order of things is naturally the main factor and any possible autonomy of an individual may be disregarded. 2. Therefore, the peculiar tragic feature of a hero is that he is doomed to adverse destiny. The predicted unfavorable lot is not totally unknown for him, although his knowledge is always only partial and obscure. The hero strives with all his outstanding abilities to overpower his fate but necessarily succumbs. A trite modern expression that denounces itself as naturalistic would term him a great loser or great as a loser. But the greatest factual loss aptly exemplifies the autonomy of an individual, which makes it legitimate to name him a person and not an animate thing. Thus, the tragic destiny generates the personal reality, though of few advanced humans only. This discovery-andemergence is extremely ambiguous. Positively, it is a definite step forward on the path of self-understanding and selfrealization. A hero takes himself seriously and has halfway included himself in his worldview. This conceptual acquisition deserves to be retained. But it is partial, tragical and scarcely bearable. Only a hero can endure his tragic destiny. Any direct generalization of his mentality as worthy of imitation by all members of a society is hardly thinkable and such a society would be inhumane and almost infernal. Human beings are no more than human beings, but not heroes or samurais (possibly a closest resemblance in a subculture). Even a quasi-heroic stoic mentality that is much less rigorous doesn't suite to everybody but only to such outstanding personalities as Epictetus or Marcus Aurelius [2]. Further, the tragic vision has a conceptual contradiction in its very core. A hero's fate is personally his own - but is impersonal in itself. This impersonal power constantly beholds him whereas he struggles blindly. For the heroic individual, his own fate remains transcendent both ontologically (it cannot be encountered as an entity to be dealt with) and epistemologically (it cannot be adequately known). The situation is essentially unequal, and it is thereby magnificent and tragic. Cf. meaning of the noun "tragedy" in contemporary colloquial English as a large-scale disaster imbued with aesthetic value for a beholder in a safe refuge (09.11.2001). Somehow ironically a sagacious observer would say the human world has becomes better, richer and more colorful thanks to the appearance of heroes provided that I'm not asked to become one of them.

This principal impasse of the heroic-tragical-aesthetic outlook was successfully and in very dissimilar ways surmounted in two developed worldview varieties. The first and the one well known both in the Mediterranean and in India is (mono)theism with its central constituent, a supernatural God. The figure of God is radically distinct from ancient polytheistic gods of early religions denoted in Christianity as paganism [3]. Those numerous gods inhabited the world and were simply much more powerful individuals than we humans. Their existence was conceived to be factual and not ontologically different from the existence of a technologically advanced civilization "in a remote galaxy". On the contrary, the God doesn't abide in the world, is not an entity. He is a person and is essentially to be met only in communication with a human person, a believer. The initial event of this non-worldly communication is a revelation as a result of which the impersonal might of tragic destiny with its burden is cancelled. Instead of blind and inexorable fate the human being encounters the God as a personality who communicates his divine will in commandments. The interpersonal communication is neither worldly interaction nor cognition of worldly objects, but it is prayer and response, it can and ought to become a communion in mutual love. Although the historically known varieties of monotheism are not always free from tragic remnants such as fear of God (which was certainly fear of fate in a non-heroic soul), the invariable trend is that towards love ontology as in Christian theology, in Sufism, in Indian Bhakti and even in Japanese Buddhist sect Jōdo Shinshū notwithstanding its being an offspring of a karmic outlook. The alleviation of the existential burden accomplished by monotheism is a principal, not a factual one (in other words, it is not worldly). The sufferings of our human condition persist, but the believers always see in them retribution of a transgression of the God's will (a sin). For example, in A. Pushkin's tragedy "Boris Godunov" the tsar Boris while dying laments his agony: "How severe is thy punishment, oh Lord!" because the poet believed that Boris was guilty in infanticide [4]. This all-encompassing explanation model of the adversities of life provides a monotheistic view the required applicability as a universal interpretation of the Being. It also affords a foundation of (heteronomous) ethics and a (perhaps 
remote) perspective of a salvation from all the sufferings and adversities on the path of faith and love.

The second solution of the tragic impasse problem is represented by a karmic vision with its widely known Indian varieties of Sankhya, Patanjali's Yoga, Buddhist schools, Jainism \& C. In it, somebody's unscrutinable fate is unmasked as the darkest, most hidden side of one's personality. We either have a natural (= inner-worldly) causal explanation of almost all events of our life or we believe in our principal ability to obtain such a one if necessary. But we also do believe that there must be exceptions, something that cannot be explained by our individual nature and life course. It is not a part of our nature, but still, a part of our personality. And in is called karma (in Sanskrit "action") as our deed performed by an individual causally related to us before our nature of the current life came into being. Therefore, it took place one of previous lives. (The vulgar expression "my previous life, "me in a previous life" are conceptually erroneous. "I" and "me" are words without reference when the speaker in unable to recollect and experience the past as "his own"). Preexistence and transmigration are necessary features of the karmic outlook. Our karma is transcendent to our consciousness and self-image but immanent to our personality, which as not a merely natural thing and is constituted by karma. So, the karmic worldview recognizes personality no less than the theistic one. But it comprises a perspective to deal with karma by means of fundamental ontological knowledge, to shift the personality boundaries by means of expanding mental clarity. The role of personality is in this outlook an operational one, it doesn't belong to the very framework of the world as was the case with theism. The karmic view also provides a perspective of getting rid of all worldly adversities. It affords a foundation of ethics which is neither naturalistic and autonomous nor theistic and heteronomous but ontological and dynamical. All seemingly undeserved sufferings and explained away as a ripening of karma. 'What evil was committed by me in a previous life because of which I'm suffering now such an ignominy!', - exclaims Shakuntala it Kalidasa's most famous nataka when the king Dushyanta neglects his own promise and doesn't recognize her as his spouse and her baby as their son [5]. It's hardly bearable but the young woman has no doubt it the order of things. Her experienced dishonor is for her surely not a blow of a blind fate but a due karmic retribution although she cannot recollect the remote cause.

Let's now mention the problems peculiar to these worldviews because we've stated that those are inevitable due to limitations of the finite human reason. The monotheistic God is necessarily summum bonum. Otherwise he would not have been essentially different from the fate ant there would be no place for love. All my calamities are results of my transgression of his commandments. So far, so good. By why did he express his will in these commandments? If I'm able to comprehend a commandment myself as a good one, I do not need any God. But if I do not, why do I think that it is essentially good and that in was the God that revealed it? The source of such a dubious commandment may pretty well be haughty and wicked. This troublesome issue is known it the history of theology.

In the karmic vision, somebody's life's adversity is due to "my" evil deed if a preexistence. But why did my predecessor commit it? If it would have been the case with everyone in those circumstances, it would have been a natural event. But karma is personal, not natural, by definition. Therefore, I have to assume an individual karmic factor specific to my predecessor. Our explanation obviously compels us to infinite temporary regress.

\section{CONCLUSION}

The ancient tragic outlook represents the first step of the consciousness on its cumbersome historical path towards self-recognition that transcends the original naturalism and naive prephilosophical view. But it was transitional and utterly unfit to become an encompassing sense-making worldview of a society. Its positive result has been kept and further developed by two alternative worldview types, the monotheistic and the karmic one. The first one introduces the conceptual frame of the person as the deepest foundation, in its trend it inevitably ontologically substantiates the second person (The God as Thou) and love. In the karmic perspective, the notion of a person is no more than operational, this worldview substantiates the first person and has a trend to an ontological, not epistemological, treatment of the knowledge. Both these worldviews are ideal types in M. Weber's sense as well as outlook attractors in Prigogine's sense and are philosophically deeper and preferable in comparison with any naturalism the scientific one included. But both are characterized by specific unsurmountable challenges.

\section{REFERENCES}

[1] An original story in an English translation: A Prose English Translation of the Mahabharata: Karna Parva. Paperback - September 10, 2010. Manmatha Nath Dutt (Translator). Cp. Hegel's deep description of the meaning of stoicism: Hegel G.W.F. Phenomenology of Spirit. Transl. by A.V. Miller Oxford, 1977, pp. 119-137.

[2] The Sanskrit vocabulary (Sanskrit-English Dictionary by Sir MonierWilliams. Numerous editions) offers a apt distinction between Ishvara or Bhagavat (God as the Lord and a polytheistic deva. Moreover, The Ishvara is called devatideva "The God above gods".

[3] Alexander Pushkin, Boris Godunov, Collected works, vol. 5, Leningrad, 1987, in Russian (the existence of an English translation is unknown to me).

[4] Kalidasa, Abhijnanasakuntalam. Edited by M.R. Kale. (Ninth ed. 1961). 